\title{
PENGARUH LITERASI KEUANGAN DAN PENDAPATAN KARYAWAN TERHADAP KEPUTUSAN INVESTASI PADA PT. KIMIA FARMA TRADING \& DISTRIBUTION (KFTD) MAKASSAR
}

\author{
Muh Syulhasbiullah ${ }^{1}$
}

${ }^{1}$ Manajamen, Fakultas Ekonomi dan Bisnis, Universitas Muslim Maros

Alamat Email : Syulhasbi@gmail.com

\begin{abstract}
ABSTRAK
Melakukan investasi membutuhkan pengambilan keputusan yang tepat dan setiap keputusan dapat mempengaruhi hasil investasi. Dalam pengambil keputusan, setiap individu akan bertindak secara rasional dan irasional, tergantung dari informasi yang diperoleh. Tujuan dari penelitian ini adalah untuk mengetahui pengaruh literasi keuangan dab pendapatan karyawan terhadap keputusan investai pada PT. Kimia Farma Trading \& Distributuion (KFTD) Makassar. Metode analisis penelitian ini menggunakan regresi linier berganda. Hasil dalam penelitian menunjukkan bahwa dampak literasi keuangan berpengaruh positif terhadap keputusan investasi PT. Kimia Farma Trading \& Distribution Makassar. Dampak pendapatan karyawan berpengaruh positif terhadap keputusan investasi PT. Kimia Farma Trading \& Distribution Makassar. Serta dampak literasi dan pendapatan karyawan berpengaruh positif terhadap keputusan investasi PT. Kimia Farma Trading \& Distribution Makassar.

Kata Kunci: Literasi Keuangan, Pendapatan, dan Keputusan Investasi.
\end{abstract}

\begin{abstract}
Making an investment requires making the right decisions and every decision can affect the return on investments. In decision makers, each individual will act rationally and irrationally, depending on the information obtained. The purpose of this study is to find out the influence of financial literacy and employee income on investment decisions on PT. Kimia Farma Trading \& Distributuion (KFTD) Makassar. This method of analysis uses linear regression. Results in the study showed that the impact of financial literacy had a positive effect on the investment decisions of PT. Kimia Farma Trading \& Distribution Makassar. The impact of employee income has a positive effect on the investment decisions of PT. Kimia Farma Trading \& Distribution Makassar. As well as the impact of literacy and employee income has a positive influence on the investment decisions of PT. Kimia Farma Trading \& Distribution Makassar
\end{abstract}

Keywords: Financial Literacy, Income, and Investment Decisions. 


\section{Jurnal Ekonomi dan Manajemen \\ e-ISSN : 2656-775X}

\section{A. PENDAHULUAN}

Investasi adalah komitmen terhadap dana atau sumber daya lain yang telah dibuat sekarang dengan tujuan memperoleh berbagai manfaat di masa depan (Tandelin 2010). Investasi menggabungkan sumber jangka panjang dengan keuntungan masa depan (Munaroh \& Sugiyono, 2019). Berinvestasi di pasar modal dapat dilakukan dengan menggunakan berbagai instrumen yang tersedia. Salah satu faktor yang diperlukan untuk berinvestasi adalah modal atau sumber daya. Sumber pembiayaan dapat berupa tabungan atau pinjaman pribadi. Selain pengetahuan tentang keuangan, pendapatan dan pengalaman investasi juga dapat mempengaruhi keputusan investasi individu. Melakukan investasi membutuhkan pengambilan keputusan yang tepat dan setiap keputusan dapat mempengaruhi hasil investasi. Dalam mengambil suatu keputusan, setiap individu akan bertindak secara rasional dan irasional, tergantung dari informasi yang diperoleh. Orang yang memiliki pemahaman yang baik tentang pengendalian keuangan biasanya memiliki lebih banyak informasi untuk menentukan jenis investasi yang diinginkan. Misalnya, individu tersebut mengetahui berbagai tingkat suku bunga serta kondisi pasar, dan mengetahui bagaimana profil risiko kredit yang berhubungan dengan keadaan keuangan pribadinya apakah cocok dengan tingkat suku bunga untuk menentukan investasi yang akan dilakukannya. Kebutuhan indivdu dan produk keuangan yang semakin kompleks membutuhkan keahlian keuangan yang memadai. Pengetahuan dan keterampilan tentang keuangan yang memahami dan berpartisipasi dalam masalah nasional di bidang keuangan seperti biaya pengobatan, pajak, investasi dan memiliki akses ke sistem keuangan. Literasi keuangan yang buruk dapat menyebabkan akses yang buruk ke lembaga keuangan. Andrew dan Linawati (2014) menggambarkan bahwa pendapatan pribadi adalah total pendapatan mentah, yang diperoleh dari upah dan usaha dari berbagai investasi. Pengahsilan yang diterima mereka berbanding lurus dengan tindakan finansial. Mereka yang berpenghasilan lebih tinggi cenderung bersifat finansial karena sumber daya yang tersedia memberi mereka kesempatan untuk bertindak lebih bertanggung jawab, yaitu semakin tinggi pendapatan seseorang, semakin baik dan lebih bertanggung jawab perilaku keuangan yang dapat mereka kelola (Purwidianto \& Mudjiyanti, 2016). Sedangkan menurut Reviandani (2019) menyatakan bahwa hubungan keputusan investasi dengan literasi keuangan adalah dengan adanya kemampuan literasi keuangan yang baik bagi setiap orang untuk mengelola keuangannya, siapapun dapat membuat keputusan investasi yang baik pula. Semakin baik literasi keuangan seseorang maka akan semakin baik pula keputusan investasi yang dibuat orang tersebut sehingga tidak akan mengalami 
kesulitan keuangan di masa yang akan datang. Dengan uraian tersebut, penulis telah menentukan judul penelitian "Pengaruh Literasi Keuangan dan Pendapatan Karyawan Terhadap Keputusan Investasi Pada PT. Kimia Farma Trading \& Distribution (KFTD) Makassar". Berdasarkan uraian latar belakang yang telah dikemukakan oleh peneliti, maka rumusan masalah dalam penelitian ini yaitu: 1) Apakah literasi keuangan berpengaruh terhadap keputusan investasi karyawan PT. Kimia Farma Trading \& Distribution Makassar? 2) Apakah pendapatan berpengaruh terhadap keputusan investasi karyawan PT. Kimia Farma Trading \& Distribution Makassar? 3) Apakah literasi keuangan dan pendapatan berpengaruh terhadap keputusan investasi karyawan PT. Kimia Farma Trading \& Distribution Makassar? Tujuan penelitian antara lain : 1) Untuk mengetahui pengaruh literasi keuangan terhadap keputusan investasi karyawan PT. Kimia Farma Trading \& Distribution Makassar, 2) Untuk mengetahui pengaruh pendapatan terhadap keputusan investasi karyawan PT. Kimia Farma Trading \& Distribution Makassar, 3) Untuk mengetahui pengaruh literasi keuangan dan pendapatan terhadap keputusan investasi karyawan PT. Kimia Farma Trading \& Distribution Makassar LIterasi keuangan menurut Soetiono dan Setiawan (2018), orang dengan literatur keuangan yang baik akan melihat uang dari perspektif yang berbeda dan mampu mengendalikan situasi secara finansial. Orang akan tetap tahu apa yang telah anda hasilkan dengan uang mereka dan bagaimana menggunakannya. Literasi secara umum berarti praktik hubungan sosial yang berkaitan dengan ilmu pengetahuan, bahasa, dan budaya, yang meliputi sarana komunikasi dalam masyarakat. Hampir semua negara bagian menaruh perhatian besar pada peningkatan literasi keuangan publik, yang pada akhirnya akan meningkatkan penggunaan keuangan publik.

Menurut Remund dalam Putri \& Hamidi (2019) indikator dari literasi keuangan, yaitu:

a. Pemahaman keuangan umum

Pemahaman keuangan publik adalah ilmu manajemen keuangan untuk membuat keputusan keuangan

b. Deposito dan pinjaman

Simpanan adalah dana masyarakat yang disimpan oleh bank dan dapat ditarik sewaktuwaktu dalam bentuk simpanan, simpanan atau deposito. Dana pinjaman yang dikeluarkan oleh bank kepada masyarakat atau kepada nasabah yang telah dibayar dengan kesepakatan antara bank dan peminjam.

c. Pertanggungan (asuransi)

Asuransi adalah polis asuransi atau perjanjian antara dua pihak dimana para pihak harus membayar iuran/premi/premi.

d. Investasi

Investasi adalah istilah yang memiliki arti berbeda yang berkaitan dengan keuangan dan ekonomi, istilah ini mengacu pada akumulasi bentuk aset tertentu dengan harapan menghasilkan keuntungan di masa depan. Menurut Khoiroh et al (2019), pendapatan 
adalah pendapatan kotor selama periode waktu tertentu dari gaji, upah, investasi dan hasil usaha, yang sering disebut sebagai "penghasilan sebelum pajak" untuk menentukan margin keuntungan individu dalam menghasilkan uang. Berdasarkan Reviandani (2019), penghasilan jelas dinilai pada beberapa hal. Penilaian ini menjadi dasar untuk menentukan berapa banyak hasil yang akan diperoleh dari apa yang telah dilakukan. Indikator untuk menilai pendapatan meliputi bonus dan insentif, pemasukan tambahan, gaji, dan investasi. Pada hakekatnya investasi adalah suatu kegiatan yang diinvestasikan, baik secara langsung maupun tidak langsung, dengan harapan pemilik modal dapat memperoleh sejumlah keuntungan dari hasil investor. Aspek keuangan merupakan salah satu faktor dalam sebuah proyek bisnis yang memudahkan perusahaan untuk bersaing atau berkembang dengan proyeksi arus kas yang akurat. Dengan menganalisis aspek keuangan yang relevan, keuntungan manajemen dapat dihasilkan untuk operasi bisnis perusahaan atau investasi mungkin bermanfaat (Nur, 2019) Menurut Tandelilin (2010), ada beberapa alasan mengapa orang berinvestasi, antara lain:

a. Untuk bertahan hidup di masa depan manusia dan orang bijak yang akan selalu memikirkan bagaimana memperbaiki cara hidup, atau setidaknya berusaha mempertahankan tingkat pendapatan sekarang agar tidak berkurang di masa depan.

b. Mengurangi tekanan inflasi, dengan berinvestasi pada properti perusahaan atau barang-barang lainnya, orang dapat menghindari risiko properti atau properti mogok karena dampak inflasi.

Keinginan untuk menghemat pajak, beberapa negara di dunia menerapkan serangkaian langkah untuk mendukung pertumbuhan investasi di masyarakat dengan memberikan keringanan pajak kepada mereka yang berinvestasi di daerah tertentu.

\section{B. METODE}

Variable yang diidentifikasi dalam penelitian adalah sebagai berikut: 1) Variabel Independent. Variabel independent dalam penelitian ini adalah literasi keuangan (X1) dan Pendapatan (X2). 2) Variabel denepndent. Variabel dependent dalam penelitian ini adalah keputusan investasi $(Y)$.

Populasi dalam penelitian ini adalah seluruh karyawan PT. Kimia Farma Trading \& Distributuion (KFTD) Makassar yang berjumlah 73 orang. Teknik pengambilan sampel menggunakan sampel jenuh. Penelitian ini menggunakan teknik pengumpulan data survei dengan menggunakan kuesioner. Analisis deskriptif digunakan untuk mengetahui karakteristik responden dan deksriptif responden terhadap indikator-indikator dalam bentuk atau merefleksikan variable. Analisa deskriptif juga ditujukan untuk menggambarkan kecenderungan tangggapan responden terhadap item-item pertanyaan yang berkaitan dengan variable penelitian. Metode kuantitatif dalam penelitian ini menggunakan regresi linier 
berganda yang bersumber dari kuisioner penelitian meliputi : 1) Uji Asumsi Klasik, 2) Uji Regresi dan 3) Uji Hipotesis.

\section{HASIL DAN PEMBAHASAN}

\section{Uji Asumsi Klasik}

a. Uji Normalitas

Uji normalitas bertujuan untuk mengetahui apakah model regresi variabel dependen dan independen berdistribusi normal atau tidak. Dari data yang telah diolah menggunakan bantuan aplikasi SPSS versi 26, diperoleh hasil:

Tabel 12. Hasil Uji Normalitas

\begin{tabular}{lll}
\hline & & $\begin{array}{r}\text { Unstandarsized } \\
\text { Residual }\end{array}$ \\
\hline $\mathrm{N}$ & & 73 \\
Normal & Mean & 0,00000000 \\
Parameters & Std. & 0,40007724 \\
& Deviation & 0,114 \\
Most Extreme & Absolute & 0,113 \\
Differences & Positive & $-0,114$ \\
& Negative & 0,114 \\
& & 0,020 \\
Test Statistic & & 0,281 \\
Asymp. Sig. (2- & & \\
tailed) & & \\
Monte Carlo & & \\
Sig. (2-tailed) & & \\
\hline
\end{tabular}

Sumber : Data diolah tahun 2021

Berdasarkan Tabel 12 di atas dapat dilihat hasil dari uji normalitas Kolmogorov-smirnov dianalisis menggunakan SPSS versi 26 dengan nilai Asymp. Sig. (2-tailed) sebesar 0,020<0,05. Namun nilai Monte Carlo Sig. (2-tailed) sebesar $0,281>0,05$ sehingga dapat disimpulkan data berdistribusi normal.

\section{b. Uji Linearitas}

Uji linearitas digunakan untuk mengetahui apakah variabel terikat dengan variabel bebas memiliki hubungan linear atau signifikan. Dari data yang telah diolah, diperoleh hasil sebagai berikut:

1) Uji linearitas variabel $X_{1}$ terhadap variabel $Y$

Tabel 1. Hasil Uji Linearitas Variabel $\mathrm{X}_{1}$ Terhadap Variabel Y

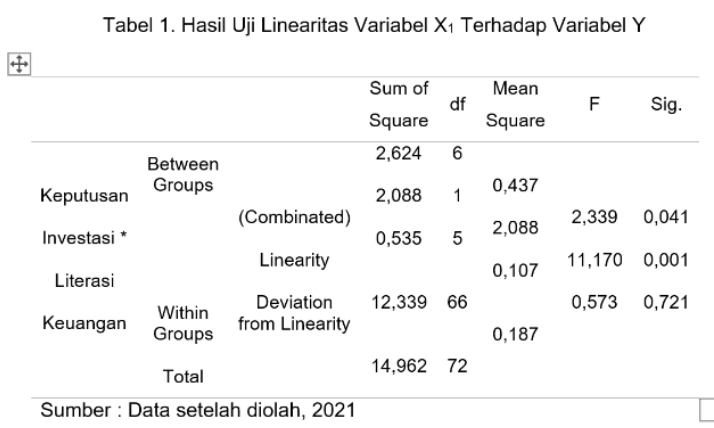

Berdasarkan Tabel 13 di atas dapat dilihat hasil dari uji linearitas dianalisis menggunakan SPSS versi 26 diperoleh nilai signifikansi Deviation from linarity $0,721>0,05$ sehingga dapat disimpulkan bahwa adanya hubungan yang linear antara variabel literasi keuangan $\left(X_{1}\right)$ dengan variabel Keputusan Investasi (Y) karyawan di PT. KFTD Makassar.

2) Uji linearitas variabel $X_{2}$ terhadap variabel $Y$ Tabel 2 Hasil Uji Linearitas Variabel $X_{2}$ Terhadap Variabel Y

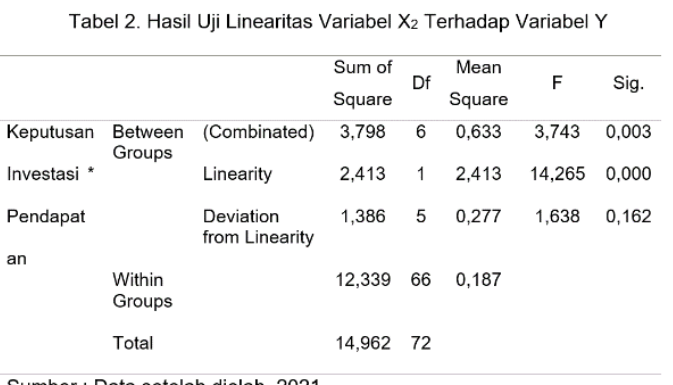

Sumber : Data setelah diolah, 2021

Berdasarkan tabel di atas dapat dilihat hasil dari uji linearitas dianalisis menggunakan SPSS 
versi 26 diperoleh nilai signifikansi Deviation from linarity 0,162 >0,05 sehingga dapat disimpulkan bahwa adanya hubungan yang linear antara variabel pendapatan $\left(\mathrm{X}_{2}\right)$ dengan variabel keputusan investasi (Y) karyawan di PT. KFTD Makassar.

\section{c. Uji Multikolinearitas}

Uji multikolinearitas digunakan untuk mengetahui apakah model regresi menemukan korelasi antara variabel independen atau bebas. Dari data yang telah diolah, diperoleh hasil sebagai berikut:

Tabel 3. Hasil Uji Multikolinearitas

$$
\text { Collinearity Statistics }
$$

Model

$$
\text { Tolerance VIF }
$$

\section{(Constant)}

Literasi

$$
0,903
$$

Keuangan

$$
0,903
$$

Pendapatan

\section{Sumber : Data setelah diolah, 2021}

Berdasarkan Tabel 15 di atas dapat dilihat hasil dari uji multikolinearitas dianalisis menggunakan SPSS versi 26 diperoleh nilai Tolerance $>0,1$ dan nilai VIF $<10$ untuk variabel X1 dan X2 sehingga dapat disimpulkan bahwa tidak terjadi multikolinearitas pada data yang diolah.

\section{d. Uji Heterokedastisitas}

Uji heterokedastisitas bertujuan menguji apakah dalam model regresi terjadi ketidaksamaan variance dari residual satu pengamatan ke pengamatan yang lain. Adapun hasil uji heteroskedastisitas yaitu sebagai berikut:

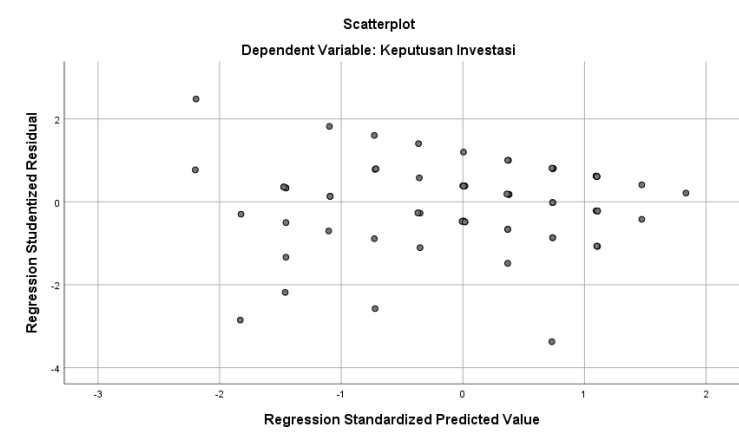

Gambar 1 Scatter Plot Hasil Uji Heteroskedastisitas

Berdasarkan Gambar 5 dapat dilihat bahwa titik-titik pada scatter plot tidak membentuk suatu pola teratur dan tersebar dibawah serta diatas angka 0 sehingga dapat disimpulkan bahwa tidak terjadi gejala heteroskedastisitas.

\section{Uji Regresi}

\section{a. Uji Regresi Linier Berganda}

Analisis regresi linier berganda merupakan regresi yang memiliki satu variabel dependen dan 2 atau lebih variabel independen. Analisis ini dugunakan untuk mengetahui arah hubungan antara variabel independen dan variabel dependen. Berikut dapat dilihat tabel data olahan menggunakan SPSS dari analisis regresi linier berganda.

Tabel 4. Hasil Pengujian Regresi Linear Berganda

\begin{tabular}{cccc}
\hline Model & B & T & Sig. \\
\hline Constant & 1,713 & 2,731 & 0,008 \\
Literasi & 0,323 & 2,495 & 0,015 \\
Keuangan & 0,318 & 2,863 & 0,006
\end{tabular}


Pendapatan

Sumber : Data setelah diolah, 2021

Berdasarkan Tabel 16 dapat dituliskan persamaan regresi sebagai berikut :

$$
Y=1,713+0,323 X_{1}+0,318 X_{2}+e
$$

Interpretasi dari koefisien persamaan di atas, dapat dijelaskan sebagai berikut :

a. Nilai konstanta sebesar 1,713 menyatakan bahwa jika variabel Literasi keuangan $\left(\mathrm{X}_{1}\right)$ dan variabel Pendapatan $\left(X_{2}\right)$ bernilai konstan, maka variabel Keputusan Investasi (Y) karyawan di PT. Kimia Farma Trading \& Distribution Makassar akan bernilai positif sebesar 1,713 .

b. Nilai koefisien regresi variabel Literasi Keuangan sebesar 0,323 menyatakan bahwa setiap kenaikan variabel Literasi Keuangan $\left(X_{1}\right)$ satu satuan, maka variabel Keputusan Investasi (Y) karyawan di PT. Kimia Farma Trading \& Distribution Makassar akan bernilai positif sebesar 0,323 dengan asumsi bahwa variabel lain bernilai konstan.

Nilai koefisien regresi variabel Pendapatan sebesar 0,318 menyatakan bahwa setiap kenaikan variabel Pendapatan $\left(\mathrm{X}_{2}\right)$ satu satuan, maka variabel Keputusan Investasi $(\mathrm{Y})$ karyawan di PT. Kimia Farma Trading \& Distribution akan bernilai positif sebesar 0,318 dengan asumsi bahwa variabel lain bernilai konstan.

\section{b. Koefisien Korelasi (R) dan Koefisien Determinasi (Adjusted $R^{2}$ )}

Tabel 17. Tabel Hasil Koefisien Korelasi (R) dan Koefisien

Determinasi (Adjusted $R^{2}$ )

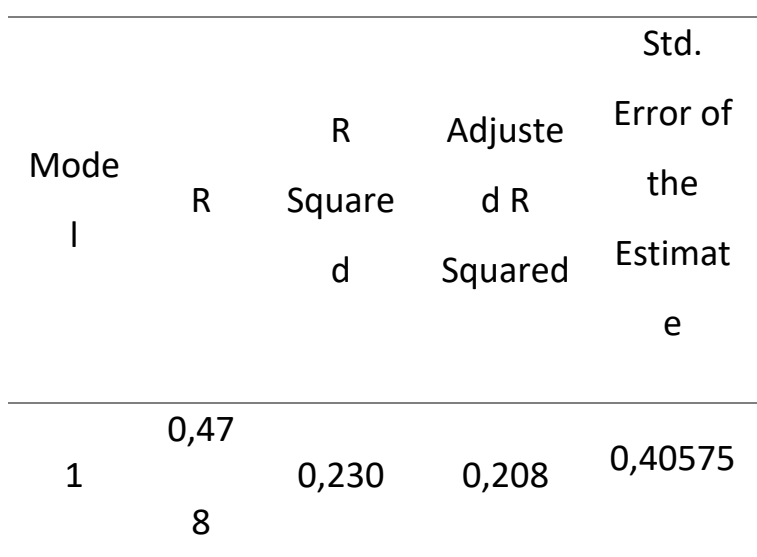

Sumber : Data setelah diolah, 2021

Berdasarkan Tabel 17 dapat dilihat nilai $\mathrm{R}$ sebesar 0,478 , hal ini menunjukan adanya tingkat hubungan yang sedang. Sedangkan nilai $R$ Squared sebesar 0,230 yang berati pengaruh literasi keuangan dan pendapatan secara simultan berpengaruh sebesar $23,0 \%$ terhadap keputusan investasi dan sisanya yaitu $77,0 \%$ dipengaruhi oleh faktor lain di luar penelitian ini.

\section{Hasil Pengujian Hipotesis}

\section{a. Hasil Uji t}

Uji t dilakukan untuk mengetahui seberapa besar pengaruh variabel independen terhadap variabel dependen. Hasil Uji t dapat dilihat pada tabel berikut ini:

Tabel 5. Hasil Uji t

\begin{tabular}{cccc}
\hline Model & B & T & Sig. \\
\hline Constant & 1,713 & 2,731 & 0,008 \\
Literasi & 0,323 & 2,495 & 0,015 \\
Keuangan & 0,318 & 2,863 & 0,006 \\
Pendapatan & & &
\end{tabular}


Sumber : Data diolah tahun 2021

Berdasarkan Tabel 18 dapat dilihat bahwa thitung untuk variabel Literasi Keuangan $\left(X_{1}\right)$ sebesar 2,495 dengan nilai signifikansi 0,015 dan $t_{\text {hitung }}$ untuk variabel Pendapatan $\left(\mathrm{X}_{2}\right)$ sebesar 2,863 dengan nilai signifikansi 0,006 . Nilai $t_{\text {tabel }}$ dengan rumus taraf besaran defiasi $n-k=73-3$ dengan menggunakan taraf tingkat kepercayaan 0,05 atau 5\% sehingga diperoleh tabel sebesar 1,99444. Sehingga dapat disimpulkan bahwa $t_{\text {hitung }}>t_{\text {tabel }}$ untuk kedua variabel yaitu literasi keuangan berpengaruh secara parsial terhadap Keputusan investasi dan pendapatan berpengaruh secara parsial terhadap keputusan investasi karyawan di PT. Kimia Farma Trading \& Distribution Makassar.

\section{b. Uji F}

Uji $F$ menunjukkan apakah semua variabel bebas yang dimasukkan kedalam model memiliki pengaruh secara simultan terhadap variabel terikat. Uji $F$ dilakukan dengan membandingkan nilai $f_{\text {hitung }}$ dengan nilai $f_{\text {tabel }}$ dengan melihat signifikan 0,05. Hasil uji F dapat dilihat pada tabeli berikut:

Tabel 6. Hasil Uji F

\begin{tabular}{cccc}
\hline Model & Df & $F$ & Sig \\
\hline Regression & 2 & 10,441 & .000 \\
Residual & 70 & & \\
Total & 72 & & \\
\hline
\end{tabular}

Sumber : Data diolah tahun 2021

Berdasarkan Tabel 19 yang dianalisis menggunakan SPSS 26 dilihat bahwa $F_{\text {hitung }}$ sebesar 10,441 dengan nilai signifikansi 0,000. Nilai $F_{\text {tabel }}$ dengan rumus $d f=(k ; n-1)$ dapat dilihat pada tabel df1 $=2$ dan $\mathrm{df} 2=70$ yaitu sebesar 3,13. Sehingga dapat disimpulkan bahwa $F_{h i t u n g}$ $10,441>F_{\text {tabel }} 3,13$ dan nilai signifikansi $0,000<$ 0,5 . Sehingga literasi keuangan dan pendapatan secara simultan berpengaruh positif terhadap keputusan investasi karyawan pada PT. Kimia Farma Trading \& Distribution Makassar.

\section{PEMBAHASAN}

\section{Pengaruh Literasi Keuangan Terhadap Keputusan Investasi.}

Berdasarkan hasil uji $t$ secara parsial diperoleh nilai $t t_{\text {hitung }} 2,495>t_{\text {tabel }} 1,99444$ tingkat signifikansi 0,015 pada $\alpha=5 \%$ dengan koefisien regresi bernilai positif sebesar 0,323 yang berarti bahwa variabel literasi keuangan secara parsial berpengaruh positif dan siginifikan terhadap keputusan investasi karyawan PT. Kimia Farma Trading \& Distribution Makassar. Oleh kerena itu dengan tingginya literasi keuangan karyawan maka keputusan investasi pun akan ikut besar, begitupun sebaliknya jika rendahnya literasi keuangan karyawan maka besar keputusan investasi akan semakin kecil.

Individu yang baru akan terjun ke dunia investasi harus memiki pengetahuan mengenai hal keuangan sehingga dapat memperoleh hasil sesuai ekspektasi. Melakukan analisis risiko atau belajar mengamati publikasi keuangan dalam mengambil keputusan adalah keniscayaan bagi orang yang mempunyai literasi tinggi mengenai hal keuangan terutama dunia investasi. Sedangkan seseorang yang mempunyai literasi rendah hanya bergantung pada saran dan 
masukan rekan yang belum tentu valid untuk diterima.

Hal ini sejalan dengan penelitian Al-Tamimi (2011) yang berjudul Factor Affecting Prices in UAE Financial Markets dengan menghasilkan kesimpulan salah satunya adalah literasi keuangan berpengaruh signifikan terhadap keputusan investor individu United Arab Emirates.

\section{Pengaruh Pendapatan Terhadap Keputusan Investasi}

Berdasarkan hasil uji $\mathrm{t}$ secara parsial diperoleh nilai $\mathrm{t} \mathrm{t}_{\text {hitung }} 2,863>\mathrm{t}_{\text {tabel }}$ 1,99444 tingkat signifikansi 0,006 pada $\alpha=5 \%$ dengan koefisien regresi bernilai positif sebesar 0,318 yang berarti bahwa variabel pendapatan secara parsial berpengaruh positif dan siginifikan terhadap keputusan investasi karyawan PT. Kimia Farma Trading \& Distribution Makassar. Oleh kerena itu dengan tingginya pendapatan karyawan maka keputusan investasi pun akan ikut besar, begitupun sebaliknya jika rendahnya pendapatan karyawan maka besar keputusan investasi akan semakin kecil.

Pendapatan yang besar akan membuat individu menjadi lebih mudah dalam memenuhi kebutuhan ataupun keinginannya dan dapat menyisihkan sebagian pendapatannya untuk ditabung demi keperluan yang mendesak di masa yang akan datang. Dengan pendapatan yang besar ini sebagian uang yang disisihkan dapat digunakan untuk berinvestasi. Sebaliknya individu yang memiliki pendapatan rendah akan cenderung kesulitan dalam berinvestasi karena pendapatan yang diperoleh hanya cukup untuk keperluan sehari-hari saja.

Hal ini sejalan dengan penelitian Dewi (2018) berjudul Pengaruh Literasi Keuangan,Pendapatan serta Masa Bekerja Terhadap Perilaku Keputusan Berinvestasi dengan salah satu kesimpulan yakni pendapatan berpengaruh signifikan terhadap perilaku keputusan investasi.

\section{Pengaruh Literasi Keuangan dan Pendapatan Terhadap Keputusan Investasi}

Berdasarkan hasil uji $F$ secara simultan diperoleh nilai $F t_{\text {hitung }} 10,441<\mathrm{F}_{\text {tabel }} 2,73$ tingkat signifikansi 0,000 pada $\alpha=5 \%$ dengan berarti bahwa variabel literasi keuangan dan pendapatan secara simultan berpengaruh positif dan siginifikan terhadap keputusan investasi karyawan PT. Kimia Farma Trading \& Distribution Makassar. Oleh kerena itu dengan tingginya literasi keuangan dan pendapatan karyawan maka keputusan investasi pun akan ikut besar, begitupun sebaliknya jika rendahnya literasi keuangan dan pendapatan karyawan maka besar keputusan investasi akan semakin kecil.

Ada beberpa faktor yang mempengaruhi keputusan investasi individu. Beberapa diantaranya adalah literasi atau kemampuan dalam memahami hal keuangan dan seberapa besar pendapatan yang diperoleh. Berdasarkan penjelasan sebelumnya diketahui bahwa kedua faktor ini merupakan faktor yang umum dijumpai di kalangan masyarakat yang baru ingin memulai terjun di dunia investasi. Pengaruh 
keduanya cenderung sejalan dengan besar kemauan individu dalam berinvestasi.

Hal ini sejalan dengan penelitian Dewi (2018) berjudul Pengaruh Literasi Keuangan, Pendapatan serta Masa Bekerja Terhadap Perilaku Keputusan Berinvestasi dengan salah satu kesimpulan yakni bahwa literasi keuangan berpengaruh positif signifikan terhadap keputusan investasi individu.

\section{PENUTUP}

\section{Kesimpulan}

Berdasarkan penelitian yang dilakukan penulis maka dapat disimpulkan sebagai berikut:

1. Literasi keuangan secara parsial berpengaruh positif signifikan terhadap pengambilan keputusan investasi pada PT Kimia Farma Trading \& Distribution Makassar.

2. Pendapatan secara parsial berpengaruh positif signifikan terhadap pengambilan keputusan investasi pada PT Kimia Farma Trading \& Distribution Makassar

Literasi keuangan dan pendapatan secara simultan berpengaruh positif signifikan terhadap keputusan investasi pada PT Kimia Farma Trading \& Distribution Makassar.

\section{Saran}

Dari hasil penelitian ini, maka penulis dapat memberikan beberapa saran antara lain :

a. Karyawan pada PT Kimia Farma Trading \& Distribution Makassar harus lebih aktif dalam meningkatkan pengetahuan keuangan dan mengikuti perkembangan ekonomi nasional sehingga dapat meningkatkan informasi keuangan yang dapat mempengaruhi kesejahteraan keuangan.

b. Lembaga keuangan non-bank harus menawarkan pelatihan pasar modal lebih lanjut sehingga informasi pasar modal dapat disebarluaskan secara luas dan seragam sehingga karyawan pada PT Kimia Farma Trading \& Distribution Makassar dapat meningkatkan pengetahuan dan kepercayaan terhadap produk dan layanannya di pasar modal.

c. Untuk peneliti selanjutnya, kami menyarankan anda melakukan penelitian dengan lebih banyak responden sehingga anda dapat melihat seperti apa tingkat literasi keuangan dan pendapatan karyawan dalam jangka panjang

\section{DAFTAR PUSTAKA}

Andrew, V, \& Linawati, N. 2014. Hubungan Faktor Demografi dan Pengetahuan Keuangan dengan Perilaku Keuangan Karyawan Swasta di Surabay. FINESTA

Dewi, I. Mertha, \& Purbawangsa, I. B. A. (2018). Pengaruh Literasi Keuangan,Pendapatan serta Masa Bekerja Terhadap Perilaku Keputusan Berinvestasi. E-Jurnal Ekonomi Dan Bisnis Universitas Udayana. https://doi.org/10.24843/eeb.2018.v07.i07 .p04

Khoiroh, S. M., Mundari, S., \& Sofianto, R. (2019). Pengaruh Digital Marketing, Profitability, Literasi Keuangan, dan Pendapatan terhadap Keputusan Investasi LAT ( Lobster 
Air Tawar ). Prosiding Seminar Nasional Teknik Industri Universitas Gajah Mada

Munawaroh, S., \& Sugiyono. (2019). Hukum Investasi. CV Jakad Publishing.

Nur, Muhammad \& Adnan Hasan, 2019. Analisis Kelayakan Invetasi Pada PT. Bank Mandiri (Persero) Tbk Yang Terdaftar Di Burse Efek Indonesia (BEI). Jurnal Ekonomi dan Manajemen e-ISSN : 2656-775X. Volume 1 No. 1, Juni 2019.

Purwidianti, Wida, \& Mudjiyanti, Rina. (2016). Analisis Pengaruh Pengalaman Keuangan Dan Tingkat Pendapatan Terhadap Perilaku Keuangan Keluarga Di Kecamatan Purwokerto Timur. Benefit: Jurnal Manajemen Dan Bisnis, 1(2), 141-148.

Putri, W. W., \& Hamidi, M. (2019). Pengaruh Literasi Keuangan, Efikasi Keuangan, dan Faktor Demografi Terhadap Pengambilan Keputusan Investasi (Studi Kasus Pada Mahasiswa Magister Manajemen Fakultas Ekonomi, Universitas Andalas Padang). Jurnal Ilmiah Mahasiswa Ekonomi Manajemen

Reviandani, W. 2019. Pengaruh Pengalaman Keuangan dan Tingkat Pendapatan terhadap Perilaku Keuangan keluarga di Desa Yosowilangun Kecamatan Manyar Gresik. Jurnal Manajerial

Soetiono, K. S., \& Setiawan, C. (2018). Literasi dan Inklusi Keuangan Indonesia. Depok: PT Raja Grafindo Persada
Tandelilin, D. E. (2010). Portofolio dan Investasi Teori dan Aplikasi (Satu). Yogyakarta: Kanisius 